\title{
Online Learning Implementation Training for Teachers of SDN Bangetayu Kulon
}

\author{
Andarini Permata Cahyaningtyas ${ }^{1 *}$, Jupriyanto², Sari Yustiana ${ }^{3}$, Rida Fironika \\ Kusumadewi $^{4}$ iD \\ 1,2,3,4 Elementary School Teacher Education Department, Universitas Islam Sultan Agung, Banten, Indonesia \\ *Corresponding author: cahyaningtyaspermata88@gmail.com
}

\begin{abstract}
During the pandemic, elementary school teachers have experienced difficulties in implementing a full online learning system because this was their first time to do it. They have not fully mastered various online learning and assessment method, so they mostly used Whatsapp as the main platform. Those problems were also faced by the teachers of SD Bangetayu Kulon. The purpose of this service is to improve the knowledge and skills of teachers towards bold learning. The subjects of this service are elementary school teachers, totaling 8 people. The training was implemented using several methods, such as lecturing, question and answer, and the direct practice method. The data were collected using observation method. The results showed that all teachers have succeeded to create and manage an online class in Edmodo and conducting online assessments by using Kahoot! and Quizizz. After this training, they will be able to conduct a more organized and interesting online learning using various platforms.
\end{abstract}

Keywords: Training, Online Learning Teacher

\section{Introduction}

Online learning has often been implemented in various education levels, but higher education became one of the institutions that most often carry out this learning method (Diki, 2013; Hudha et al., 2018; Rahardjo et al., 2016; Sari, 2012). Online learning is a learning system that is not done face-to-face, but uses a platform that can help the teaching and learning process that is carried out even though it is far away (Oktafia \& Wulandari, 2020). Online learning is learning carried out with the help of the internet both synchronously and asynchronously which provides opportunities for student interaction with learning resources, both educators / the environment and their peers (Dong et al., 2020). The existence of online learning provides opportunities for students to share opinions and learn more independently without any time limit and more flexible space (Hwang et al., 2020; Kkese, 2020; Lage-Cala et al., 2020).. In addition to the ability, of course, online learning must also pay attention to the financial conditions of students and the facilities and infrastructure that support online learning (Rusli et al., 2020). Especially now that online learning is one solution that can be done to prevent the spread of COVID-19 and reduce student anxiety in dealing with sudden life changes (Hussein et al., 2020). Online learning is that really requires the ability of educators and students, because the ability to use technology will really help create a more conducive learning atmosphere, so that good social interactions are formed (Andel et al.,

$\begin{array}{lll}\text { History: } & & \text { Publisher: Undiksha Press } \\ \text { Received } & : 02 \text { December } 2020 & \text { Licensed: This work is licensed under } \\ \text { Revised } & : \text { 16 December } 2020 & \text { a Creative Commons Attribution 3.0 License } \\ \text { Accepted } & : 06 \text { February } 2021 & \text { CC OP OF } \\ \text { Published } & : 25 \text { February } 2021 & \end{array}$


2020). So, online learning is effectively applied in the current situation and the role of the teacher is very much needed in designing and implementing online learning

Indonesian Government through the Ministry of Education and Culture instructed teachers and students in each level of education to conduct the learning process from home via Circular Letter Number 3 of 2020. This will be a new challenge for Indonesian teachers because so far, the learning process has always been carried out face to face in the classroom. In Semarang, online learning has been conducted since The Governor of Central Java, Ganjar Pranowo, issued an order last March (Nashr, 2020). Therefore, teachers should adapt quickly to be able to operate online learning platforms. Besides, teachers should implement learning methods that can stimulate students, so they will be active and able to solve problems that occur during the lesson (Costley \& Lange, 2017). This also applies to the choice of the online learning strategies chosen by teachers to make students interested in learning organized by them. There are three categories of online learning (Kattoua et al., 2013): 1) Self-paced independent study, teachers provide the materials, the evaluation, and the feedback; while students arrange their schedule. They can learn using those materials based on their own pace and thinking capacity, review the materials, and evaluate the result by themselves. 2) Asynchronous interactive, students and teachers participate in the learning process although it is not conducted at the same time. They join in the online classroom whenever they need. They can leave comments and questions about the materials and the teachers will reply to them later. This approach offers help and feedback from the teachers and peers, and usually, it will not be as "relax" as in the self-paced independent study. Synchronous interactive, students join in live learning and conduct question and answer activities using email or realtime live chat. This is the most interactive learning process and closest to the implementation of face-to-face learning. However, this cannot be implemented flexibly because the schedule has been fixed and students and teachers should spare their time to focus on the lesson. Those three categories have their advantages and disadvantages, so teachers should decide wisely by considering students' needs and characteristics, this is not easy for some teachers because they are not used to it. SDN Bangetayu Kulon is one of the schools where teachers experience difficulties in implementing online learning and assessment. So far, the majority of online learning has been carried out using Whatsapp as the main platform for delivering evaluation materials and questions. Therefore, it is necessary to hold training on the implementation of online learning for SDN Bangetayu Kulon teachers so that they can then apply a more varied online learning and assessment.

The existence of online learning training can improve teachers' understanding of online learning (Mardawani et al., 2020). Training provides opportunities for teachers to be more skilled in designing learning and implementing online learning (Pujiyanti \& Mulyawati, 2021). This description is supported by research results which state that training is one strategy for implementing offline-based learning, so that students are not tied to the internet network (Sabarua et al., 2020). The training is able to develop the skills of the trainees in making technology-free learning media (Sriyanti et al., 2015). Training for teachers can improve their ability to support bold learning during the current Covid-19 pandemic (Azizah, 2020). So, training can provide teachers' experience, skills, and understanding of the learning process. The purpose of this service is to improve the knowledge and skills of teachers towards bold learning. Effective training will have an impact on the quality of teachers and will certainly have an impact on the quality of bold learners.

\section{Materials and Methods}

This training was implemented in several stages, starting in August 2020. The team visited SDN Bangetayu Kulon to decide the schedule of the activity, and it was agreed that 
the training would be held on September 7-10, 2020. The subjects of this service are elementary school teachers, totaling 8 people. The training was implemented using several methods, such as lecturing, question and answer, and the direct practice method. The material related to the variables was delivered using the lecturing method, simultaneously with the question-and-answer method to minimize the lack of understanding experienced by teachers during the explanation. Therefore, the direct practice method was conducted after the concept of online learning and assessment has been understood, so the teachers would be easier to operate the websites and applications. The initial interview was conducted to find out about the need of the teachers with The Headmaster of SDN Bangetayu Kulon. Based on the interview, the teachers mostly needed training in managing online learning and assessment. This was because during the pandemic, they had to implement a full online learning system and they were still using Whatsapp as the main platform. Thus, the headmaster advised the team to hold an online learning and assessment training using certain platforms that are easy to manage. After knowing the needs of the teachers of SDN Bangetayu Kulon, the planning was conducted to determine the scope and the time allocation for each material. Then, it is decided that this training would be divided into four days, and the materials would be specified on Edmodo, Kahoot!, and Quizizz. Those three were chosen because they are easy to be managed. Teachers do not need to install the application because it can be accessed using websites through a smartphone or a laptop. Furthermore, the team planned to hold the training online and offline, because, at that time, it was still forbidden to gather with many participants and for a long time. The offline session was held to explain the materials, discuss some problems, and practice the steps in managing the platforms; while the online session was held in the last days for individual practice, and the question and answer session was conducted by using emails and Whatsapp chat.

\section{Results and Discussion \\ Day 1: Online Learning Training using Edmodo}

The first day of training was held on September 7, 2020. Teachers were explained about online learning and what kind of alternative platforms are suitable for elementary students. First, the MC opened the training session, and it was continued by the headmaster to give an opening speech. Second, MC introduced the presenters who joined in the training for four days. After that, the teachers were invited to conduct an ice-breaking session so they could concentrate more and be more ready to follow the agenda.

Next, the MC explained the objective of this activity before she gave the time to the first speaker. The first material was about online learning and its platforms that were conveyed by using a lecturing method. It was started by explaining what is online learning, its characteristics, its advantages, and disadvantages, and what kind of platforms are suitable for elementary students. Question and answer were not held in a specific session but were conducted simultaneously and naturally when teachers found the explanation was not so clear. Teachers could also tell about their problem in conducting online learning, so the solution can be discussed together with the other teachers and the speakers.

After that, the training continued to the direct practice to create an online classroom by using Edmodo. Some teachers used smartphones, and some others used a laptop to be able to follow the instruction from the speaker. The teachers were enthusiastic to join in a group discussion because they can help each other while creating and managing their online classroom. With help from the team, all questions about the managerial process in using Edmodo could be accommodated well. 


\section{Day 2 and 3: Online Assessment Training using Kahoot! and Quizizz}

In the second meeting, the speaker explained about the online assessment and what kind of platforms can be used to evaluate students' cognitive achievement, such as Google Form, Kahoot!, Quizizz, Mentimeter, etc. Just like on the first day, the MC opened the meeting before the time was given to the speaker. Teachers were asked what platforms they usually use, and it was found out that most of them only used Google Form or asked the students to come to school to collect the assignments. So, they were interested to use another method to assess students' learning outcomes.

Before the practice was started, the teachers were asked to conduct a quiz session by using Kahoot!. Through this quiz, teachers were given a chance to try how is feeling to have an online quiz using this platform. They were enthusiastic, followed the instruction well, and tried to be the first. After found out about the result, they were eager to learn how to use Kahoot! because they could evaluate their result individually, check the wrong and right answers, and also find out their score directly. Then, by using their gadget, they started to create an account in kahoot.com and created their quiz. Sometimes, some teachers asked several questions about what kind of quiz they could create in Kahoot!, how to share the link with their students, and how to see the result. The team members helped them to solve all problems by guiding them step by step, and at the end of the day, they were already successful to create a quiz and share it with their students.

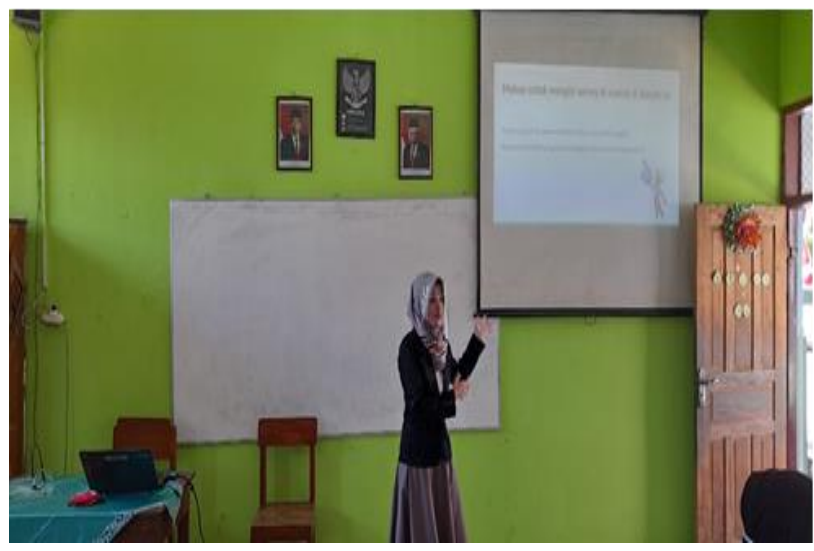

Figure 1. The Explanation of Online Learning Concept

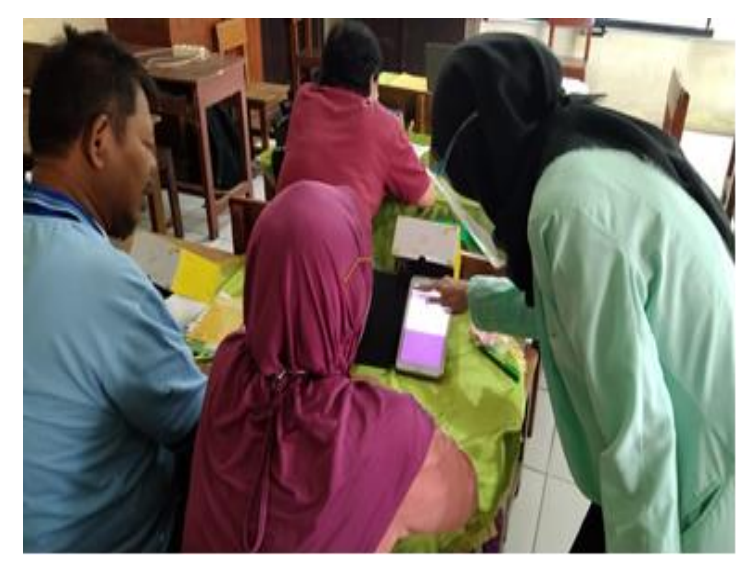

Figure 2. The Team Members Helped the Teachers to Create an Online Quiz

On the third day, the training started with an opening speech by MC and then immediately move to the Quizizz practice session. This was because the material had been delivered at the previous meeting. The teachers were invited to create a cognitive evaluation by using Quizizz. They were explained what was the differences between Kahoot! and Quizizz, so then they could choose the most suitable with their and the students' preferences. First, they were allowed to try a quiz that was prepared by the team. Just like before, they felt enthusiastic and tried hard to be the first. In Quizizz, you could see the right answer and how many questions they got right. After that, they were grouped into pairs and tried to create a quiz by the following instructions from the team. An hour later, some group had finished 10 questions, while others still in question 5 or 6 . The pair who finished the quiz then demonstrated in front of the class and asked the other teachers to be their students. The demonstration was a success and they were satisfied with the result. The pairs who had not finished the quiz continued to work together and succeeded to show the quiz to the others. 
During the training, some problems occurred among the teachers related to smartphones. Some of them were still using an old phone so it proceeded the task quite long. Some teachers connected their phones to school Wi-Fi, but the connection was not good enough so they felt frustrated because they could not catch up with the other's progress. However, regardless of those constraints, they were very active and cooperative to follow the training.

\section{Individual Practice and Online Consultation}

On day 4, after the teachers succeeded to operate Edmodo, Kahoot! and Quizizz in a group, they conducted an individual practice at home. They were welcome to consult with the team, including conducting the pilot test of their online class and quiz, during work time. Therefore, those who had mastered and do not need to consult anymore were welcome to send the quiz link as the final assignment of the training.

\section{The Evaluation of the Program}

From this training, it was found that six homeroom teachers and two subject teachers have succeeded in creating an online class and quiz and sharing it with their students. Hence, it concluded that the training objectives have been accomplished. However, there were several things to note if the team wants to hold a similar training about online learning, such as informing the teachers to provide quota so they can prevent a connection problem if the Wi-Fi does not work. Furthermore, the teachers need to practice often so they will be more proficient in managing online classes and quiz. Table 1 shows the recapitulation of the teachers' ability to create an online class and quiz.

Table 1. The Recapitulation Data of the Teachers' Ability to Create an Online Class and Quiz

\begin{tabular}{|c|c|c|c|c|}
\hline & \multirow{2}{*}{ APPS } & \multirow{2}{*}{ Indicators } & \multicolumn{2}{|c|}{ The Number of Teachers } \\
\hline & & & Success & Failed \\
\hline \multirow[t]{6}{*}{1} & \multirow[t]{6}{*}{ EDMODO } & Creating an online class & 8 & 0 \\
\hline & & $\begin{array}{l}\text { Inviting students to join the online } \\
\text { class }\end{array}$ & 8 & 0 \\
\hline & & Sharing the materials & 8 & 0 \\
\hline & & Replying to students' comments & 8 & 0 \\
\hline & & Giving assignments & 8 & 0 \\
\hline & & Creating a quiz & 8 & 0 \\
\hline \multirow[t]{3}{*}{2} & \multirow{3}{*}{$\begin{array}{l}\text { Kahoot! } \\
\text { and } \\
\text { Quizizz }\end{array}$} & Creating an online quiz & 8 & 0 \\
\hline & & Inviting students to join & 8 & 0 \\
\hline & & $\begin{array}{l}\text { Assessing students' cognitive skills } \\
\text { using the result }\end{array}$ & 8 & 0 \\
\hline
\end{tabular}

\section{Discussion}

Covid-19 pandemic has been greatly affected students' psychological condition as the result of the unpreparedness of the system and the human resources to conduct online learning. Students are easily bored with the online learning after half month, feel restless because their parents have difficulty to provide quota, have emotional disturbance because of too many assignments (Irawan et al., 2020). Besides, internet connection, facilities, lessskilled students and teachers in utilizing gadget, less-motivated students and parents, and teachers' ability in conveying the lesson materials have also become challenges in online learning system (Robianto, 2020). Furthermore, boredom will be academic risk factors that endamage motivation and performance in learning environment (Parker et al., 2018). This 
can not be allowed if the teachers want their students to successfully comprehend the materials. They should find a way to help students overcome their difficulties and start to enjoy online learning, for example is by using various platforms suitable for the children's characteristics and the learning objectives. That problems were also found in SDN Bangetayu Kulon. The teachers who were not used to using online learning platforms but Whatsapp need to be introduced to other several options so they can choose what the best platform to teach online is. Teachers as the training participants experienced a new option to manage an online class besides using Google Classroom. Moreover, the online quiz also becomes an effective solution to conduct an online assessment during the pandemic. By mastering the use of multiple online learning platforms, teachers would have options to choose which one will be the most suitable one to be implemented in their class, by considering their students' characteristics, the lesson materials, and students' learning facilities.

Online learning has been a form of transformation of the human way of thinking in communication and collaborating (Garrison, 2017). In a self-paced independent study, teachers provide the lesson materials and evaluations for a certain period, which is equipped with answer keys, discussions, and assessment guidelines. This makes students more independent in adjusting their learning schedule. However, the minus point of this category is that students cannot interact with their teachers directly. Therefore, in asynchronous interaction, students and teachers indirectly interact with each other, and in different moments. Teachers can use email, blog, or other platforms such as Edmodo and Google Classroom to share the materials and assessments, while students can access it later. Students can also ask questions about the materials and teachers will reply when they read them. This what makes it different from synchronous interactive, which allows both parties to interact and discuss the materials at the same time.

Edmodo is one of the learning platforms that helps teachers to manage their online learning easily. Edmodo has several advantages, such as being able to help students to develop their knowledge through group discussion compared to individual learning (Balasubramanian et al., 2014). Edmodo also gives opportunities for teachers and students to share folders contains lesson materials and worksheets. Besides, students can participate actively during the learning process, and they will pay more attention to the quality of their work (Purnawarman et al., 2016). Edmodo can be functioned as a synchronous and a synchronous learning platform, and this will be an advantage for teachers and students in implementing online learning because they are able to choose between those options. If not all the students can join in synchronous interactive learning, teachers will function Edmodo as asynchronous platform by sending materials in the subject folders and the wall, then allow students to comment whenever they are able to.

Teachers also have responsibility to assess their students achievement in learning the materials. This can be held in every lesson, at the last meeting of the week, in the middle and end of semester. During this pandemic, teachers should also conduct the assessment involving web tools known as e-assessment. Based on the research, students' perception towards e-assessment is positive, because it enables a better interaction among students and teachers, and let learners (Cohen \& Sasson, 2015). Online assessment can be held in a quiz form. It has been proven that combining online quizzes with other instructional activities in teaching strategy is very appreciated by the students due to its benefit to help them keep up with the lesson, involve them deeply in learning activities, and increase their cognitive achievement (Salas-Morera et al., 2012).

There are several platforms to help teachers in conducting online quizzes, such as Kahoot! and Quizizz were considered easy to access by teachers and students. Those have benefits as online assessment platforms because those can shuffle the questions and answer 
options given by the teachers, so it will be difficult for students to cheat. They also do not need to wait for others to start the quiz. Moreover, the questions are presented as a quiz with limited time so it will challenge the students more, and they can get the score and find out their rank right after they finish all the questions (Chaiyo \& Nokham, 2017). This kind of online quizzes cannot only be implemented during a full online learning system. Even if the school activities has been back to the usual, or if teachers use blended learning in the future, they can still use Kahoot! and Quizizz to assess the students' cognitive learning outcome because the inclusion of online quizzes gives a good contribution in succeeding the implementation of blended learning (Spanjers et al., 2015).

Apart of synchronous learning, Edmodo, Kahoot!, and Quizizz can help teachers to conduct an asynchronous interactive learning. By doing so, teachers can be flexible in preparing materials and help students to adjust their time during learning from home activities. They also can check their students' participation intermittently and make an appointment to conduct synchronous learning with the students (Daniel, 2020). Based on the observation, teachers showed that they were enthusiastic to learn those platforms. They found it easy and accessible for them to be used regularly. These platforms will absolutely help teachers to avoid students' boredom and they will have good options to do if the synchronous learning cannot be applied because of some reasons, such as slow connection can affect students in giving responses, and students who have not mastered managing the platform will fall behind the others (Manhas, 2017). That is why teachers should have some alternatives in choosing the online learning and assessment platforms that can facilitate all students fairly. Hence, Edmodo, Kahoot!, and Quizizz can be good alternatives to conduct online learning and assessment because those three can be accessed synchronously and asynchronously.

So, the existence of online learning training can improve teachers' understanding of online learning (Mardawani et al., 2020). Training provides opportunities for teachers to be more skilled in designing learning and implementing online learning (Pujiyanti \& Mulyawati, 2021). This description is supported by research results which state that training is one strategy for implementing offline-based learning, so that students are not tied to the internet network (Sabarua et al., 2020). The training is able to develop the skills of the trainees in making technology-free learning media (Sriyanti et al., 2015). Training for teachers can improve their ability to support bold learning during the current Covid-19 pandemic (Azizah, 2020). So, training can provide teachers' experience, skills, and understanding of the learning process.

\section{Conclusion}

This training aimed to develop teachers' ability in conducting online learning and assessment. Based on the process and the result of the training, it is found that they enthusiastically created an online class in Edmodo and an interesting online quiz using Kahoot! and Quizizz. They were able to do all of the instructions given by the team. In the end, they have been fully mastered how to manage those platforms and how to check their students' participation. However, they should still use it routinely so they will be more advance in implementing online learning. Hopefully, this training will bring good impacts for teachers and students during this pandemic and in the future.

\section{Acknowledgement}

Our gratitude goes to Universitas Islam Sultan Agung for providing permission and opportunities so that this training can be realized. The gratitude is also given to the headmaster and teachers of SDN Bangetayu Kulon who have been willing to be cooperative so this training can run smoothly. 


\section{References}

Andel, S. A., de Vreede, T., Spector, P. E., Padmanabhan, B., Singh, V. K., \& Vreede, G. J. de. (2020). Do social features help in video-centric online learning platforms? A social presence perspective. Computers in Human Behavior, 113(April), 106505. https://doi.org/10.1016/j.chb.2020.106505.

Azizah, A. (2020). Pelatihan Pembelajaran Daring Dimasa Pandemi Covid-19 Untuk GuruGuru Sd Negeri 3 Melayu Muara Teweh Online Learning Training During the Covid 19 Pandemic for Teachers Sd Negeri 3 Malay Muara Teweh. BAKTI BANUA : Jurnal Pengabdian Kepada Masyarakat, 1(2), 78-83. https://ejurnal.stimibjm.ac.id/index.php/BBJM/.

Balasubramanian, K., Jaykumar, V., \& Fukey, L. N. (2014). A Study on "Student Preference towards the Use of Edmodo as a Learning Platform to Create Responsible Learning Environment." Procedia - Social and Behavioral Sciences, 144, 416-422. https://doi.org/10.1016/j.sbspro.2014.07.311.

Chaiyo, Y., \& Nokham, R. (2017). The effect of Kahoot, Quizizz and Google Forms on the student's perception in the classrooms response system. 2017 International Conference on Digital Arts, Media and Technology (ICDAMT), 178-182. https://doi.org/10.1109/ICDAMT.2017.7904957.

Cohen, D., \& Sasson, I. (2015). Journal of Technology and Science Education. Journal of Technology and Science Education, 5(3), 184-193.

Costley, J., \& Lange, C. H. (2017). ideo lectures in e-learning: Effects of viewership and media diversity on learning, satisfaction, engagement, interest, and future behavioral intention. Interactive Technology and Smart Education, 14(1), 14-30. https://doi.org/10.1108/ITSE-08-2016-0025.

Daniel, S. J. (2020). Education and the COVID-19 pandemic. Prospects, 49(1-2), 91-96. https://doi.org/10.1007/s11125-020-09464-3.

Diki, D. (2013). International Collaboration of Distance Learning Universities for Online Learning in Indonesia. Lux, 2(1), 1-8. https://doi.org/10.5642/lux.201301.12.

Dong, C., Cao, S., \& Li, H. (2020). Young children's online learning during COVID-19 pandemic: Chinese parents' beliefs and attitudes. Children and Youth Services Review, 118(June), 105440. https://doi.org/10.1016/j.childyouth.2020.105440.

Garrison, D. R. (2017). E-learning in the 21 st century: A community of inquiry framework for research and practice (Third ed.). Routledge.

Hudha, M. N., Chaeruman, U. A., Aji, S. D., Huda, C., Yusro, A. C., Kumala, F. N., Wartono, W., Nandiyanto, A. B. D., \& Abdullah, A. G. (2018). SPADA: Online learning between universities of PGRI Indonesia. MATEC Web of Conferences, 197, 1-6. https://doi.org/10.1051/matecconf/201819703002.

Hussein, E., Daoud, S., Alrabaiah, H., \& Badawi, R. (2020). Children and Youth Services Review Exploring undergraduate students ' attitudes towards emergency online learning during COVID-19: A case from the UAE. Children and Youth Services Review, 119(August), 105699. https://doi.org/10.1016/j.childyouth.2020.105699.

Hwang, G. J., Wang, S. Y., \& Lai, C. L. (2020). Effects of a social regulation-based online learning framework on students' learning achievements and behaviors in mathematics. Computers and Education, 160, 104031. https://doi.org/10.1016/j.compedu.2020.104031.

Irawan, A. W., Dwisona, D., \& Lestari, M. (2020). Psychological Impacts of Students on Online Learning During the Pandemic COVID-19. KONSELI: Jurnal Bimbingan Dan Konseling (E-Journal), 7(1), 53-60. https://doi.org/10.24042/kons.v7i1.6389.

Kattoua, T., Al-Lozi, M., \& Alrowwad, A. (2013). A Review of Literature on Knowledge 
Management using ICT in Higher Education. International Journal of Business Management and Economic Research (IJBMER), 4(1), 62-67.

Kkese, E. (2020). McGurk effect and audiovisual speech perception in students with learning disabilities exposed to online teaching during the COVID-19 pandemic. Medical Hypotheses, 144(July), 110233. https://doi.org/10.1016/j.mehy.2020.110233.

Lage-Cala, S., Folgueras-Díaza, M. B., Alonso-Hidalgoa, M., García-Menéndezb, D., \& Fernández-Garcíab, F. J. (2020). Investigation of the effectiveness of online learning tools for energy performance certificates preparation. Energy Reports, 6, 609-614. https://doi.org/10.1016/j.egyr.2019.09.034.

Manhas, P. S. (2017). Strategic e-learning models in brand building of educational institution. IV Международной Заочной (Электронной) Научной Конференции, Посвященной 60-Летию Филологического Факультета БашГУ, 15-16.

Mardawani, M., Fusnika, F., \& Hartini, A. (2020). Pelatihan Pembelajaran Daring Google Classroom Bagi Guru Di Smp Negeri 6 Sintang. JURNAL PEKAN: Jurnal Pendidikan Kewarganegaraan, 5(2), 148-156. https://doi.org/10.31932/jpk.v5i2.935.

Nashr, J. A. (2020). Ini instruksi Ganjar untuk aturan belajar di rumah karena Corona. 16 Maret.

Oktafia, I. H., \& Wulandari, S. S. (2020). Pembelajaran Daring Sebagai Upaya Study From Home (SFH) Selama Pandemi Covid 19. Jurnal Pendidikan Administrasi Perkantoran, 8(3). https://doi.org/10.1093/fampra/cmy005.

Parker, P. C., Perry, R. P., Chipperfield, J. G., Hamm, J. M., \& Pekrun, R. (2018). An attribution-based motivation treatment for low control students who are bored in online learning environments. Motivation Science, 4(2), 177-184. https://doi.org/10.1037/mot0000081.

Pujiyanti, D., \& Mulyawati, I. (2021). Pelatihan Penggunaan Media Pembelajaran Berbasis Online Bagi Guru Terdampak Covid-19 di SMPN 126 Jakarta. Jurnal Solma, 10(01), 170-178. https://journal.uhamka.ac.id/index.php/solma/article/view/5028/2272

Purnawarman, P., Susilawati, \& Sundayana, W. (2016). The use of Edmodo in teaching writing in a blended learning setting. Indonesian Journal of Applied Linguistics, 5(2), 242-252. https://doi.org/10.17509/ijal.v5i2.1348.

Rahardjo, D., Sumardjo, Lubis, D. P., \& Harijati, S. (2016). Internet access and usage in improving students' self-directed learning in Indonesia open university. Turkish Online Journal of Distance Education, 17(2), 30-41. https://doi.org/10.17718/tojde.90196.

Robianto, R. (2020). Pengembangan Media Ajar Berbasis Cross-Platform. 7(4), 247-255.

Rusli, R., Rahman, A., \& Abdullah, H. (2020). Student perception data on online learning using heutagogy approach in the Faculty of Mathematics and Natural Sciences of Universitas Negeri Makassar, Indonesia. Data in Brief, 29, 105152. https://doi.org/10.1016/j.dib.2020.105152.

Sabarua, J. O., Patalatu, J. S., \& Besare, S. D. (2020). Pelatihan Pembelajaran Daringbagi Guru-Guru Sekolah Dasar Guna Meningkatkan Literasi Digital Di Masa Pandemi Covid-19. Jurnal Abdimas Ilmiah Citra Bakti, 1(2), 147-155. https://doi.org/10.38048/jailcb.v1i2.122.

Salas-Morera, L., Arauzo-Azrofa, A., \& García-Hernández, L. (2012). Análisis de los cuestionarios online como herramientas de enseñanza y evaluación. Revista de Tecnología y Educación Científica, 2(1), 39-45.

Sari, E. R. (2012). Online learning community: a case study of teacher professional development in Indonesia. Intercultural Education, 23(1), 63-72. https://doi.org/10.1080/14675986.2012.664755.

Spanjers, I. A. E., Könings, K. D., Leppink, J., Verstegen, D. M. L., de Jong, N., 
Czabanowska, K., \& van Merriënboer, J. J. G. (2015). The promised land of blended learning: Quizzes as a moderator. Educational Research Review, 15, 59-74. https://doi.org/10.1016/j.edurev.2015.05.001.

Sriyanti, I., Muslim, M., \& Yusup, M. (2015). Pelatihan Pembuatan Media Pembelajaran Berbasis E-Learninng Bagi Guru SMA Srijaya Negara Palembang. Jurnal Inovasi Dan Pembelajaran Fisika, 2(1), 12-18. 